\title{
Isolated common iliac artery dissection and aneurysm
}

\author{
Hanae Ida, Naoki Taniguchi
}

Okinawa Prefectural Chubu Hospital, Uruma City, Okinawa, Japan

\section{Correspondence to} Dr Hanae Ida,

hany.mo087@gmail.com

Accepted 13 March 2016
CrossMark

To cite: Ida $\mathrm{H}$, Taniguchi $\mathrm{N}$. BMJ Case Rep Published online: [please include Day Month Year] doi:10.1136/ bcr-2016-214989

\section{DESCRIPTION}

A 49-year-old man, with a history of well-controlled hypertension, presented with sudden left lower quadrant abdominal pain after defaecation. The severity of the pain was scaled as 1-2 over 10 and the pain was continuous. There were no digestive symptoms. On admission, vital signs were as follows: blood pressure $130 / 70 \mathrm{~mm} \mathrm{Hg}$, pulse rate $70 \mathrm{bpm}$, respiratory rate 18 breaths $/ \mathrm{min}, \mathrm{SpO}_{2} 97 \%$ and body temperature $37.4^{\circ} \mathrm{C}$. On physical examination, the abdomen was soft and flat and the bowel sound was normal. There was tenderness on the left side of the umbilicus. Neither rebound nor guarding was noted. Pulses in the peripheral arteries were well palpable and equal. There were no specific signs suggestive of any connective tissue diseases such as Marfan syndrome. Laboratory data were within normal limits. Contrast-enhanced CT revealed a dissection and aneurysm formation in the left common iliac artery (figure 1). The patient was diagnosed as having isolated left common iliac artery dissection.

Isolated common iliac artery dissection is a very rare disease; we are aware of only a few case reports. In those articles, the possible causes included atherosclerosis, fibromuscular dysplasia, connective tissue disease, trauma and pregnancy. ${ }^{12}$

In the present case, the only risk factor was hypertension and it has, to date, been wellcontrolled with medication. Exhaustive hormonal studies for secondary hypertension were negative. At present, the patient is being treated conservatively with antihypertensive medications. However, serial imaging tests should be obtained in order to observe the possibility of further enlargement or rupture. $^{3}$ Surgical or endovascular treatment may be necessary in the future.

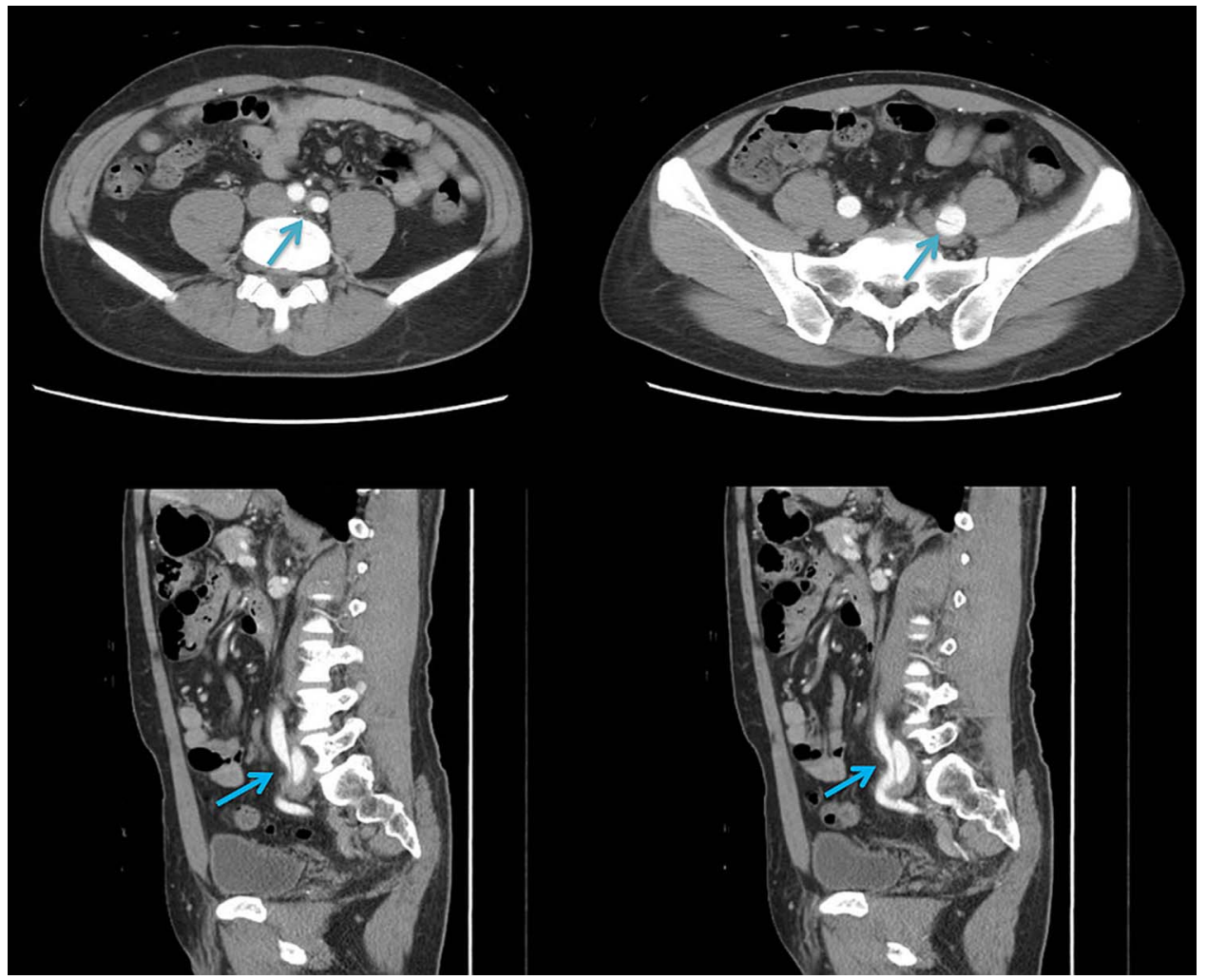

Figure 1 Blue arrow showing isolated iliac artery dissection and aneurysm, with a diameter of $17 \mathrm{~mm}$. The thrombosed false lumen of the left common artery root tended to be retracted. There was no other dissection and no aneurysm. 


\section{Learning points}

- One differential diagnosis of abdominal pain in the emergency department can be iliac artery dissection, especially when there is left-sided, acute, continuous pain. Check for an ischaemic organ as a possible diagnosis.

- Follow-up imaging is important to decide the timing of operation and the size.

- Evaluation of the risk factors for isolated iliac artery dissection includes not only atherosclerosis, and also connective tissue disease including Ehlers-Danlos syndrome, Marfan syndrome, fibromuscular dysplasia, trauma and pregnancy.
Contributors $\mathrm{HI}$ cared for the patient and NT observed the management and followed up the patient from a cardiovascular surgeon's view of point.

Competing interests None declared.

Patient consent Obtained.

Provenance and peer review Not commissioned; externally peer reviewed.

\section{REFERENCES}

1 Honjo O, Yamada Y, Kuroko Y, et al. Spontaneous dissection and rupture of common iliac artery in a patient with fibromuscular dysplasia: a case report and review of the literature on iliac artery dissections secondary to fibromuscular dysplasia. J Vasc Surg 2004;40:1032-6.

2 Declemy S, Kreitmann P, Popoff G, et al. Spontaneous dissecting aneurysm of the common iliac artery. Ann Vasc Surg 1991;5:549-51.

3 Hatsune T, Mori Y, Umeda Y, et al. A case report of ruptured isolated common iliac artery aneurysm with a maximum diameter of $22 \mathrm{~mm}$. J Jpn Coll Angiol 2013;53:39-41.

Copyright 2016 BMJ Publishing Group. All rights reserved. For permission to reuse any of this content visit http://group.bmj.com/group/rights-licensing/permissions.

BMJ Case Report Fellows may re-use this article for personal use and teaching without any further permission.

Become a Fellow of BMJ Case Reports today and you can:

- Submit as many cases as you like

- Enjoy fast sympathetic peer review and rapid publication of accepted articles

- Access all the published articles

- Re-use any of the published material for personal use and teaching without further permission

For information on Institutional Fellowships contact consortiasales@bmjgroup.com

Visit casereports.bmj.com for more articles like this and to become a Fellow 